\title{
Determinant of Interest in Paying Zakat with Age as a Moderating Variable (Study on Minang Society)
}

\author{
Harmaini $^{1}$, Yuswar Zainul Basri' ${ }^{2}$, Willy Arafah $^{3}$ \\ IEF Trisakti University \\ Jalan Kyai Tapa No. 1 Grogol, Jakarta Barat, Indonesia \\ e-mail: harmaini@trisakti.ac.id ${ }^{1}$, yuswarzainalbasri@gmail.com ${ }^{2}$, $\underline{\text { willy.arafah@trisakti.ac.id }}^{3}$
}

\section{To cite this document :}

Harmaini, Basri, Y.Z., \& Arafah, W. (2023). Determinant of Interest in Paying Zakat with Age as a Moderating Variable (Study on Minang Society). Aptisi Transactions on Management (ATM), 5(1), 92-104.

DOI :

https://doi.org/10.33050/atm.v7i2.1821

\section{Abstract}

This study wants to test whether there is an influence between Zakat Knowledge, Religiosity, Culture, Subjective Norms, and Income on Muzaki Minang's zakat interest in paying zakat, with age as a moderating variable. The purpose of this study will be to analyze and describe the effect of Muzaki Minang's interest in tithing by using a theoretical model. The data collection technique used a questionnaire and sampling was done by purposive sampling with a total of 320 respondents. The population in this study is the Muzaki Minang population who live in West Sumatra and outside West Sumatra. The data analysis technique used is descriptive statistical analysis. The results of this study are the knowledge of zakat and culture variables do not affect Muzaki's interest in zakat. While the interest in paying zakat which has a significant and positive effect is religiosity, subjective norms, and income. There is a moderate relationship between income and age with interest in paying zakat. The dominant age factor is early adulthood (20-40 years) compared to old age (>40 years). The findings of this study are helpful input for the leaders of the indigenous people of West Sumatra in strengthening the understanding of the younger generation about Minang customs. With the increasing understanding of adat for the Minang community, they are interested in paying zakat themselves and using zakat as a tool to improve people's welfare.

Keywords: Zakat, Religiosity, Culture, Income, Intention to Pay Zakat

\section{Introduction}

Muzakki is people or institutions subject to the obligation to pay zakat on property ownership that has reached the nishab and haul. Zakat is one of the pillars of Islam that is obligatory for someone who can do it [1]. Muzaki, who have met the requirements for obligatory zakat include Muslims, mature and intelligent, full ownership of property, reaching nisab, and reaching haul.

At first, the Minangkabau culture adhered to the philosophy of "Alam Takambang Jadi Guru," a philosophy of life that is guided by nature, with the arrival of Islam, then perfected, a philosophy and view of life emerged adaik basandi syara', syara' basandi kitabullah." Syara'mangato Adata Mamakai" This expression shows the unification of the concept of adat with Islam [2]. This means that it is based on customs that are supported by Islamic religious law in the Qur'an and Hadith.

A strong belief in Islam is a hallmark of the Minangkabau community, as indicated by the population of West Sumatra, who adheres to Islam by $98 \%$ (BPS, 2021). Apart from the above characteristics, Minang people are synonymous with merantau (Tsuyoshi Kato, 2005). In general, 
when Minang men can find money, they will go out of their area of origin (meantau). The proverb says "karatau madang dihulu, babuah babungo balun, merantau bujang dahulu dirumah paguno balun" (Naim 1984), the meaning of this proverb is that men in Minangkabau feel it is better to leave their hometown because they feel they are not needed at home. This proverb is also an impetus for Minangkabau men to go abroad to achieve material success. Initially, this tradition of wandering was based on the use of the area in processing natural resources around the West Sumatra region and also the lack of employment opportunities so that it had an impact on the low level of welfare of the Minangkabau community, this was what triggered and forced them to migrate to try their luck outside West Sumatra [3].

Putra et al. (2019), with a research entitled Motivation of Minangkabau Migrants Domiciled in Tanjung Karang District, Bandar Lampung City Center, stated that intrinsic motivation is Minangkabau custom which demands migration, self-esteem as a Minangkabau man, and rigidity or obedience to being bound traditional ties. Extrinsic motivation is the progress of Lampung, open job market opportunities, many markets, and Lampung people [4]. This opinion is supported by research by Asmon and Adri (2021) entitled Motivation to Migrate in Late Minangkabau Adolescents. The study results indicate that the dominant factor influencing reasons for migration in Minang youth in the age range of 19-25 years to migrate for educational purposes is $51,72 \%$. Meanwhile, the main reason for the largest respondents of Minang people to go abroad is to achieve success, which is $51.72 \%$.

From the explanation above, it can be concluded that the reasons for the Minangkabau people to go abroad are 1). Go to school (Education). To get a good school, they will be willing to separate from their families. 2). Because of work, many Minang people live outside West Sumatra because they are placed outside West Sumatra. 3). Reasons for economic improvement [5]. The goal of the Minang people to migrate is to change their fate from Mustahik to Muzaki. Migrants who are known as diaspora, if they return to their village, they are more honored, this is in accordance with the hadith of the Prophet, honor the guest. The success of the diaspora will be demonstrated by a high level of education, high experience, and abundant wealth. By themselves they can also raise the dignity of their family, relatives and village people, and make shelter like a banyan tree in the middle of Koto "Ureknyo tampek baselo, batangnyo tampek basanda, buahnyo buliah dimakan, bungonyo ambiak kasuntiang, daunnyo tampek balinduang, tampek balinduang kapanehan, tampek bataduah kahujanan. It means the roots are cross-legged (sitting), the tree to lean on, the fruit can be eaten, the flowers are edited, the leaves are a shelter when it's hot and shelter when it rains. So great is the hope for the success of the Minang sons in wandering if it is associated with Zakat muzaki Minang can lift his people from poverty [6].

Zakat is believed to bridge between the rich and the needy in solving economic problems, the problem faced is the not yet significant function of zakat in reducing poverty levels [7]. Many studies have proven that zakat is a good instrument in solving the problem of poverty. West Sumatra is one of the provinces with a Muslim population of 97.42 percent and has obliged the State Civil Apparatus (ASN) to pay zakat (Sari, Dian Fitriarni, Irfan Syauqi Beik, 2019). West Sumatra, which has a Muslim majority population and still firmly adheres to religious principles, has a relatively high potential for zakat, infaq, sadaqah, waqf, and others [8]. However, this great potential has not been managed and utilized optimally, so it has not significantly impacted solving poverty and existing problems (Taheransyah. Syamsurizal \& Zahirman, 2020).

Zakat is very closely related to income, so income is the main element of people's lives that affects the willingness to pay zakat. Previous studies include Sedjati, et al. (2018), (Nugroho \& Nurkhin, 2019), (Nurkholis \& Jayanto, 2020), Hapsari \& Priyadi (2020), Kartika (2020), proving that income has a positive and significant effect on the interest of muzaki in paying zakat. However, Mirawati, Malik, and Ibrahim (2018), (Huda \& Ghofur, 2012), Maulana (2020), Utami, et al. (2021) prove that income does not have a significant effect on the willingness of muzaki to pay zakat. This means that when a person's income has reached the nishab (the minimum calculation of income subject to zakat), the person feels that his income is still not sufficient to meet the various needs of life, so it is too small to influence the willingness to pay zakat especially Maulana (2020).

Religiosity is one of the influential factors (Yazid, 2017), (Ridlwan \& Sukmana, 2017), (Sedjati et al., 2018), (Setiawan, 2019), (Mirawati et al., 2019), Maulana (2020), and Maulidina \& Solekah (2020), Nurkholis and Jayanto (2020), Utami, et, al (2021) all prove that religiosity has a positive and significant effect on muzakki interest in paying zakat. However, Nugroho \& Nurkhin 
(2019), Syafira, Ratnasari \& Ismail (2020), prove that religiosity has no significant effect on muzakki's interest in paying zakat.

Another factor is the cause of people's willingness to pay zakat. Among them are Subjective Norm Variable is where each individual will never be separated from the influence of his environment, parents, siblings, children, spouses, colleagues, and people around him in making decisions [9]. (Nurkholis \& Jayanto, 2020) states that the environment has a positive and significant effect on interest in paying zakat (Alpriyamah \& Adityawarman, 2017), (Pratiwi, 2018), proving that Subjective Norms have a positive and significant effect on interest in paying zakat.

\section{Research Method}

This research includes explanatory and qualitative, a study model to find and explain causal relationships between variables through hypothesis testing using a quantitative approach and will be analyzed qualitatively and quantitatively to explain the causal relationship between variables through hypothesis testing and variable analysis - the research variables. By testing the variables related to zakat knowledge, religiosity, culture, subjective norms, and income on the interests of Muzakki Minang Zakat [10].

The instrument used in this study was a questionnaire instrument to determine knowledge of zakat, religiosity, culture, subjective norms, and income on Muzaki Minang's interest in paying zakat. The scale used in the questionnaire preparation is the ordinal scale, often called the Likert scale. This Likert scale allows respondents to express the intensity of their feelings [11].

\subsection{Population}

The population is a collection of all possible individuals, objects, or measurements that are observed (Anderson et al., 2019). Population in statistics refers to a group of individuals with distinctive characteristics of a study's concern [12]. These specific characteristics or characteristics can be used to make conclusions (Sanusi, 2019). The population in this study is the Minang ethnic who fulfills the requirements to pay zakat, both domiciled in West Sumatra or outside West Sumatra (Overseas).

\subsection{Sample}

The sample is part of the population to be studied (Anderson et al., 2019). The sample is part of the population taken or determined based on specific characteristics and techniques [13]. To describe the characteristics, the sample must truly represent the population. Therefore, it is necessary to use the procedure used to select a portion of the sample to obtain a representative research sample, such as population characteristics [14]. Considering the large population size and limited research time and costs, samples were taken to estimate the nature of the population [15].

The sampling technique used in this research is purposive sampling, a non-random sampling technique where the researcher determines the sample by determining special characteristics by the research objectives so that it is expected to answer the research problem [16]. The research sample used was 320 respondents with considerations not too much and not too little. The criteria for selecting the sample are the Minang tribe who meet the mandatory requirements for zakat in Islam, namely Muslim, mature and reasonable, property owners must be complete, reach nishab, and reach haul (until the specified time) [17].

\subsection{Method of Collecting Data}

The data collection method was carried out to obtain two types of data, namely primary and secondary data. Data collection is carried out to obtain the information needed in order to achieve the research objectives, then the data collection techniques can be carried out as follows:

\section{Primary data}

In this study, primary data was obtained from the field in the following ways:

a. Questionnaire

The survey method aims to collect information from respondents using a questionnaire containing a list of questions asked directly to the respondents, namely Minang people who are Muslim who meet the requirements for compulsory zakat, both domiciled in West Sumatra and abroad). The questions presented in the questionnaire are closed questions. Respondents only need to choose 1 out of 5 options for the statements submitted. Assessment of respondents' answers using a 
5-point Likert scale indicates the level of agreement and disagreement with a scale of 1 (strongly disagree) to 5 (strongly agree). To obtain data that, if processed, shows the influence or relationship between variables.

b. Interview

Interviews were conducted with informants related to zakat.

\section{Secondary Data}

The method used in secondary data collection is data taken from official bodies in published reports such as the Central Statistics Agency, National Development Planning Agency, and other sources related to this dissertation.

\subsection{Literature Review}

1. Zakat

Zakat as an aspect of growth and development can also be interpreted, zakat can elevate mustahik (people who receive zakat) to muzakki (people who give zakat) this is known as productive zakat (Suryanto, 2018). According to (Tambunan et al., 2019), in his research entitled "Analysis of Cointegration of Zakat and Indonesia's Economic Growth for the 2015-2018 Period, concluded that zakat affects Indonesia's economic growth both in the short and long term.

Zakat is the third pillar of Islam, vertical and horizontal dimensions [18]. In the vertical relationship between humans and the Creator, who carries out His Shari'a, Zakat is an obligation and part of the pillars of Islam, which is most important after prayer [19]. In the Qur'an, the word zakat is mentioned 32 times, 28 of which are side by side with the word prayer. This shows that zakat is obligatory, and the command to pay zakat is almost parallel to the command to pray among the Qur'anic verses that explain zakat are the 56th verse of Annur verse which reads:

And establish prayer, pay zakat, and obey the Messenger, may you be given mercy."

\section{Conditions for Compulsory Zakat}

Zakat has legal requirements. According to the agreement of the Ulama, the mandatory conditions for zakat are as follows (Al-Zuhayli 2008):

1. Independent

Zakat is imposed on people who are free and can act freely. According to the agreement of the scholars, zakat is not obligatory on enslaved people who do not have property rights.

2. Muslim

According to ljma' zakat is not obligatory on unbelievers because this zakat is a holy mahdah worship, while non-believers are not obligated to pay zakat.

3. Baligh and sensible

Zakat is not obligatory to be taken on the property of small children and crazy people because both are not included in the provisions of people who are obliged to perform worship such as prayer and fasting.

4. Full property ownership.

Assets to be issued zakat must be purely personal property and not mixed with the property of others. If our wealth is mixed with other people's property while we are going to issue zakat, we must first remove the other person's property.

5. Reaching nisab

Nisab is the limit of whether wealth is obliged to pay zakat or not according to the provisions of syara' as a sign of a person's wealth and the levels that require zakat. If the property owned by a person has reached the nisab, then the wealthy are obliged to pay zakat, if it has not reached the nisab then zakat is not obligatory.

6. Reach haul

The haul is wealth owned by a person when it has reached one year of hijriyah or has reached the period that requires someone to issue zakat. While the legal condition is the intention that accompanies the implementation of zakat. 


\section{Religiosity}

Religiosity is conceptualized as an individual's adherence to religious beliefs and practices (Delener, 1990). Psychological and sociological research widely discussed the relationship between religion and various behavioral, affective, and cognitive phenomena [20]. Research in cross-cultural management and consumer behavior has noted the impact of religion on culture, profoundly influencing societies and individuals' values, norms, and symbols.

\section{Culture}

(Koentjaraningrat, 2000) defines culture as the whole system of ideas, actions, and human creations in social life, which are made into human beings by learning. Meanwhile, according to Selo Soemardjan and Soelaiman Soemardi in their book A Flower of Sociology, culture is all the works, tastes, and creations of society [21]. The two opinions above (Prasetyo, 2020) formulate that culture is everything created by humans, an inner expression of individual personality and group personality carried out from generation to generation and by the times. (Abdurrahman, 2011), said that cultural values are conceptions, ideas, norms, and other forms (implied and explicit) that influence the choice of ways, goals, actions and are seen as important in life.

\section{Subjective Norm}

(Fishbein \& Ajzen, 1977) in "theory of reasoned action," Subjective Norm is a person's perception of social pressure to perform or not to perform a behavior. According to (Marhaini, 2008), a person's behavior depends on the intention, then the intention to behave depends on the attitude and subjective norms. Belief in behavior and evaluation will determine behavior. Normative beliefs and motivation to follow the opinions of others will determine subjective norms [22]. The theory of subjective attitudes and norms is also known as the Theory of Reasoned Action, introduced by Fishbein and Ajzen. Mas'ud (2012) states that intention is used. Attitude is a person's positive or negative feelings towards behavior or object. Subjective norms (subjective norms) are social influences that influence a person to behave. A person will desire an object or behavior if the people around him influence him or he believes that the environment or people around him support what he does [23].

Subjective norms are individual perceptions of social pressure to do/not perform certain behaviors. Subjective norms can be determined and measured as a set of normative beliefs regarding the agreement/disagreement of a significant reference to a behavior (Refiana, 2002 in Santoso and Indarini, 2010). Subjective norms are determined by two things, namely:

1. Normative belief relates to people's expectations and desires about what behavior should be done and what should not be done (Azjen, 1980)

2. Motivation to Comply is the extent to which a person's motivation to follow the expectations of individuals or reference groups.

\section{Income}

Sources of income can be material, such as land or non-material, such as work or both. So that income is divided into income, salary/wages, and profits. Income is basically the remuneration received by the owner of the factors of production for their sacrifices in the production process [24]. Each factor of production, such as land, will receive remuneration in the form of salary/wages, and expertise, including entrepreneurs, will receive remuneration in the form of profit (Parkin, 2019).

There are two ways to distribute income in Islamic values, namely compulsory contributions (zakat) and voluntary contributions (infaq) [25]. For someone whose income has met the conditions for issuing zakat (nisab and haul), it is obligatory for him to pay zakat. So that income can influence someone to issue zakat [26]. With income, it can be seen whether it has reached the nisab, from this income it can also affect the amount of zakat issued. As in the research of Kanji et al. (2011), states the level of income in addition to encouraging people to issue zakat also affects the value of zakat issued [27]. 


\section{Age Factor}

Age grouping in this study refers to (Hurlock et al., 1994), which is divided into two age groups, namely the immature age or referred to as early adulthood aged 20-40 years and mature age (late adulthood) aged over $>40$ years. What is meant by adulthood is the age at which individuals can adapt independently and social expectations [28]. Able to define their problems well enough to be stable and emotionally mature enough.

\section{Result and Discussion}

Respondents in this study are the Minangkabau who are Muslim who meet the requirements in issuing zakat, whether they are domiciled in West Sumatra or outside West Sumatra (Overseas). The respondent's profile can be seen from several characteristics: (1). Gender with male and female categories. (2). Age, with categories $20-30$ years, $31-40$ years, $41-50$ years, and above 50 years. (3) Domicile, who lives in West Sumatra and outside West Sumatra (Overseas). (4). Professions consist of Lecturers, Teachers, Doctors, ASN, BUMN Employees, Private Employees, and others. (5) Monthly income by category; IDR 7.5 million IDR 10 million, IDR 10 million - 15 million, IDR 15 million - IDR 20 million, and above IDR 20 million.

1. Description of Zakat Knowledge Variables

In this study, the variable Knowledge of Zakat $(P)$ is reflected in five indicators. The description of each indicator of the zakat knowledge variable is shown in the table 1.

\begin{tabular}{|c|c|c|c|}
\hline Code & Indicator & Mean & $\begin{array}{l}\text { Standard } \\
\text { Deviation }\end{array}$ \\
\hline P1. & $\begin{array}{l}\text { As far as I know, zakat is a number of } \\
\text { assets that must be issued. }\end{array}$ & 4,884 & 0,503 \\
\hline P2. & $\begin{array}{l}\text { As far as I know, the income received } \\
\text { from any business when it reaches the } \\
\text { Nisab, zakat must be issued. }\end{array}$ & 4,841 & 0,465 \\
\hline P3. & $\begin{array}{l}\text { As far as I know, the legal basis for } \\
\text { zakat is the Qur'an and hadith. }\end{array}$ & 4,913 & 0,314 \\
\hline P4. & $\begin{array}{l}\text { I understand the nisab or the level of } \\
\text { zakat obligatory assets. }\end{array}$ & 4,584 & 0,638 \\
\hline P5. & $\begin{array}{l}\text { As far as I know, the purpose of zakat is } \\
\text { to achieve socio-economic justice. }\end{array}$ & 4,666 & 0,702 \\
\hline \multicolumn{2}{|r|}{ Average Zakat Knowledge Variables } & 4,778 & 0,374 \\
\hline
\end{tabular}

Table 1. Descriptive Statistics of Zakat Knowledge Variables

From table 1 above, the overall average for the zakat knowledge variable is 4.778 , which means that the knowledge of zakat owned by the respondents is excellent because the respondents know the number of assets and income that must be spent on tithing, understand the level of obligatory assets in tithing. In addition, respondents also know the legal basis for zakat comes from the Qur'an and hadith, and respondents know the purpose of zakat in order to achieve social and economic justice. The average value of the standard deviation of the zakat knowledge variable is 0.374 , which means that the distribution of respondents' answers is relatively homogeneous. 
2. Description of Religious Variables

Religious variables are reflected by five indicators. The description of each indicator of the Religious variable is shown in table 2.

\begin{tabular}{|c|l|l|l|}
\hline Code & \multicolumn{1}{|c|}{ Indicator } & \multicolumn{1}{|c|}{ Mean } & \multicolumn{1}{|c|}{$\begin{array}{l}\text { Standard } \\
\text { Deviation }\end{array}$} \\
\hline R1. & $\begin{array}{l}\text { I pay zakat because of my belief } \\
\text { (religious/the ideological). }\end{array}$ & 4,853 & 0,449 \\
\hline R2. & $\begin{array}{l}\text { I pay zakat because of religious practice } \\
\text { (the ritualistic). }\end{array}$ & 4,569 & 0,854 \\
\hline R3. & $\begin{array}{l}\text { I pay zakat because of religious } \\
\text { experience (religious feeling/the } \\
\text { experiment). }\end{array}$ & 4,222 & 1,122 \\
\hline R4. & $\begin{array}{l}\text { I pay zakat on religious knowledge (the } \\
\text { intellectual). }\end{array}$ & 4,625 & 0,798 \\
\hline R5. & $\begin{array}{l}\text { I pay zakat on practice (religious effect } \\
\text { accordingly). }\end{array}$ & 4,794 & 0,532 \\
\hline & Average Religiosity Variable & $\mathbf{4 , 6 1 3}$ & $\mathbf{0 , 6 0 7}$ \\
\hline
\end{tabular}

Table 2. Descriptive Statistics of Religious Variables

From table 2 above, the overall average of the religiosity variable is 4.613 , which means that the religious level of the respondents is considered high, because they pay based on their beliefs by religious practices, besides that respondents also pay zakat based on experience that has been done long ago. Because of their religious knowledge and experience, respondents consider paying zakat an obligation. The average value of the standard deviation of the religiosity variable is 0.607 , which means that the distribution of respondents' answers is quite varied.

3. Description of Cultural Variables

The cultural variable is reflected by four indicators. The description of each indicator of the Culture variable is shown in table 3.

\begin{tabular}{|c|l|l|l|}
\hline Code & \multicolumn{1}{|c|}{ Indicator } & \multicolumn{1}{|c|}{ Mean } & \multicolumn{1}{|c|}{$\begin{array}{l}\text { Standard } \\
\text { Deviation }\end{array}$} \\
\hline B1. & $\begin{array}{l}\text { In paying zakat, I prioritize Mustahik } \\
\text { from the closest family. }\end{array}$ & 4,456 & 0,902 \\
\hline B2. & $\begin{array}{l}\text { By paying Zakat proof of my concern for } \\
\text { less fortunate families. }\end{array}$ & 4,694 & 0,608 \\
\hline B3. & $\begin{array}{l}\text { By paying Zakat, it means reducing the } \\
\text { suffering of Mustahik. }\end{array}$ & 4,644 & 0,591 \\
\hline B4. & $\begin{array}{l}\text { By paying zakat, it is my pride in helping } \\
\text { others. }\end{array}$ & 4,291 & 1,120 \\
\hline
\end{tabular}




\begin{tabular}{|l|l|l|}
\hline Average Cultural Variables & $\mathbf{4 , 5 2 1}$ & $\mathbf{0 , 6 3 2}$ \\
\hline
\end{tabular}

Table 3. Descriptive Statistics of Cultural Variables

From table 3 above, the overall average for the Culture variable is 4.521 , which means that the respondent has a very high level of culture, where the respondent in terms of paying zakat prioritizes mustahik from the closest family. Paying zakat is proof of concern in helping others, less fortunate families, and reducing the suffering of mustahik. The average value of the standard deviation of the Culture variable is 0.632 , which means that the distribution of respondents' answers is quite varied.

4. Description of Subjective Norm Variables

Subjective variables are reflected by five indicators. The description of each indicator of the Subjective Norm variable is shown in table 4.

\begin{tabular}{|c|c|c|c|}
\hline Code & Indicator & Mean & $\begin{array}{l}\text { Standard } \\
\text { Deviation }\end{array}$ \\
\hline N1. & $\begin{array}{l}\text { I pay zakat because it is a habit from my } \\
\text { parents. }\end{array}$ & 4,231 & 1,146 \\
\hline N2. & $\begin{array}{l}\text { I pay zakat because of encouragement } \\
\text { from relatives/other family members. }\end{array}$ & 3,719 & 1,390 \\
\hline N3. & $\begin{array}{l}\text { I pay zakat because I learn from my } \\
\text { Ustad (teacher/lecturer). }\end{array}$ & 4,216 & 1,071 \\
\hline N4. & $\begin{array}{l}\text { I pay zakat because I want to practice } \\
\text { the pillars of Islam. }\end{array}$ & 4,884 & 0,399 \\
\hline N5. & $\begin{array}{l}\text { I pay zakat because I want to get the } \\
\text { pleasure of Rizki which I receive from } \\
\text { Allah SWT. }\end{array}$ & 4,894 & 0,356 \\
\hline \multicolumn{2}{|c|}{ Average Subjective Norm Variables } & 4,389 & 0,710 \\
\hline
\end{tabular}

Table 4. Descriptive Statistics Subjective Norm Variables

From table 4 above, the overall average for the Subjective Norm variable is 4.389 , which means that the norms embedded in the respondents are considered high, where respondents pay zakat to carry out the pillars of Islam and want to get ridho from Allah SWT. In addition, respondents are also used to encouraging their parents/other family members about paying zakat. Next, paying zakat is also because they get lessons from Ustad (teachers/lecturers), the religious knowledge possessed by the respondents is classified as good. The average value of the standard deviation of the Subjective Norm variable is 0.710 , which means that respondents' answers vary. 


\section{Description of Income Variables}

Income variables are reflected by five indicators. The description of each indicator of the Religious variable is shown in table 5.

\begin{tabular}{|c|l|c|c|}
\hline Code & \multicolumn{1}{|c|}{ Indicator } & Mean & $\begin{array}{c}\text { Standard } \\
\text { Deviation }\end{array}$ \\
\hline P1. & $\begin{array}{l}\text { The wages/salaries I get are obligatory } \\
\text { for me to pay zakat. }\end{array}$ & 4,728 & 0,632 \\
\hline P2. & $\begin{array}{l}\text { The profit I get is obligatory for me to } \\
\text { pay zakat. }\end{array}$ & 4,697 & 0,676 \\
\hline P3. & $\begin{array}{l}\text { I pay zakat after my income or wealth } \\
\text { has reached the nisab. }\end{array}$ & 4,734 & 0,561 \\
\hline P4. & $\begin{array}{l}\text { With increasing income, the amount of } \\
\text { zakat income also increases. }\end{array}$ & 4,797 & 0,531 \\
\hline P5. & $\begin{array}{l}\text { I feel that my income actually increases } \\
\text { after paying zakat. }\end{array}$ & 4,691 & 0,614 \\
\hline & Average Income Variables & $\mathbf{4 , 7 2 9}$ & $\mathbf{0 , 4 8 3}$ \\
\hline
\end{tabular}

Table 5. Statistics Description of Income Variables

From table 5 above, the overall average on the Income variable is 4.729 , which means that the income obtained by the respondent is enormous. Wages/salaries obtained by respondents are an obligation in paying zakat. Every time get a profit, don't forget to pay zakat. Usually, respondents pay zakat after their assets reach the nisab because as income increases, the amount of income that must be tithed also increases. By paying zakat, respondents feel that their income will increase. The average value of the standard deviation of the Income variable is 0.483 , which means that the distribution of respondents' answers is quite varied.

\section{Variable Description of Interest in Paying Zakat}

Variable interest in paying zakat are reflected by five indicators. The description of each indicator of the Religious variable is shown in table 6.

\begin{tabular}{|c|l|l|l|}
\hline Code & \multicolumn{1}{|c|}{ Indicator } & \multicolumn{1}{|c|}{ Mean } & \multicolumn{1}{|c|}{$\begin{array}{l}\text { Standard } \\
\text { Deviation }\end{array}$} \\
\hline M1. & $\begin{array}{l}\text { Paying zakat is an impulse from within } \\
\text { the individual. }\end{array}$ & 4,731 & 0,621 \\
\hline M2. & Paying zakat has a social motive. & 4,516 & 0,845 \\
\hline M3. & Paying zakat is not an emotional factor. & 4,413 & 0,905 \\
\hline
\end{tabular}




\section{Average Variable Interest in Paying Zakat

Table 6. Statistics Description Variable Interest in Paying Zakat

From table 6 above, the overall average for the variable interest in paying zakat is 4.553 , which means that the respondent's interest in paying zakat is high because paying zakat is encouragement from oneself. In addition, there is a social motive, and there is no emotional factor in paying zakat. The average value of the standard deviation of the variable interest in paying zakat is 0.654 , which means that the distribution of respondents' answers varies.

\subsection{Problem}

Based on the background of the problem, phenomenon, and research gap, the identification of problems in this study are:

There is a big difference between the potential for zakat receipts and the realization of zakat receipts as in West Sumatra, as presented in table 1.3. Even though the Muslim population in West Sumatra is $97.42 \%$ and the West Sumatra Regional Government has also required ASN to pay zakat (Sari, et al., 2019). This indicates low interest in paying zakat to zakat recipient institutions.

The not yet significant function of zakat in poverty alleviation in an area, this occurs in the area of West Sumatra as stated by (Sari, Dian Fitriarni, Irfan Syauqi Beik, 2019) Zakat is part of the pillars of Islam and is a form of worship with dimensions of maaliyah ijtima'iyah, namely worship related to property, economy and social society [29]. If zakat is appropriately managed, it can be a driving force for the economy, as Tambunan et al. (2019) argued, zakat affects Indonesia's economic growth both in the short and long term.

Minang Muslims firmly hold religion and culture that strongly influence decision-making behavior in paying zakat, in contrast to other regions [30]. It was also found that the behavior of Minangkabau Muslims was not optimal in paying zakat according to (Asyari, 2016), where their faith had a low value but high rituals.

Minang people tend to distribute their zakat to their families even though they are abroad because they assume who will care about their families if not themselves, there is even a saying that "children in the lap of nephews are guided by villagers to be roasted". This means that responsibility is not only for children but also for social responsibility for the progress of nieces and nephews and is even wider for brothers and sisters in the same village and ethnicity [31].

\section{Conclusion}

This research was conducted to answer research questions about the factors that could potentially influence Muzaki Minang's interest in paying zakat. In accordance with the results of the discussion in this study, Zakat Knowledge does not significantly affect Muzaki Minang's interest in paying zakat. Religiosity has a positive and significant effect on muzakki's interest in paying zakat, Minangkabau culture has no significant effect on Muzaki's interest in paying zakat, subjective norms have a positive and significant effect on muzaki's interest in paying zakat. Income has a positive and significant effect on muzaki interest in paying zakat. Furthermore, the moderating variable Age Factor strengthens the relationship of all direct and significant variables to Muzaki Minang interest in paying zakat, namely the age factor can moderate the relationship between Zakat knowledge and Muzaki Minang interest in paying zakat. The age factor moderated the relationship between religiosity and Muzaki Minang's interest in paying zakat. The age factor moderates the relationship between Minangkabau culture and Muzaki Minang's interest in paying zakat. The age factor moderated the relationship between Subjective Norms and Muzaki Minang's interest in paying zakat. Age factor moderates the relationship between income and Muzaki Minang's interest in paying zakat. 
The results of this study indicate that the variable knowledge of zakat, and culture does not affect the interest of Muzaki to pay zakat. Religion, subjective norms, and income have a positive and significant effect on the interest of Muzaki to pay zakat. Age factor is able to moderate the relationship between zakat knowledge and the interest of muzaki to pay zakat. The age factor is able to moderate the relationship between religiosity and the interest of muzaki to pay zakat. The age factor is able to moderate the cultural relationship to the interest of muzaki to pay zakat. The age factor is able to moderate the relationship between Subjective Norms and interest to pay zakat. The age factor is able to moderate the relationship between income and interest of muzaki to pay zakat. The early adult age factor (20-40 years) is more dominant than the elderly age (> 40 years).

Further researchers are advised to collect a broader sample, both for the West Sumatra region itself or the Diaspora at home and abroad, so that the resulting research will be more comprehensive and can be applied more generally. It is necessary to examine the stratified sample between Muzaki, who have high and moderate opinions. The next researcher can make zakat modeling in Muzaki Minangkabau with different analytical tools so that the Zakat modeling represents the unique characteristics of Muzaki Minang.

\section{References}

[1] T. Mariyanti, Y. Z. Basri, and J. Jazuli, "The Basic Factors Driving The Intention To Pay Zakat," APTISI Trans. Manag., vol. 6, no. 1, pp. 30-41, 2022.

[2] H. Mukhibad, F. Fachrurrozie, and A. Nurkhin, "Determinants of the intention of muzakki to pay professional zakat," Share J. Ekon. dan Keuang. Islam, vol. 8, no. 1, pp. 45-67, 2019.

[3] S. Purnama, A. Sukmasari, and R. Bhandari, "The Role of Religiosity as a Mediating Variable in the Relationship between Online Transactions and Customer Satisfaction and Loyalty in Islamic Banking," Aptisi Trans. Manag., vol. 5, no. 2, pp. 143-151, 2021.

[4] A. C. Andam and A. Z. Osman, "Determinants of intention to give zakat on employment income: Experience from Marawi City, Philippines," J. Islam. Account. Bus. Res., 2019.

[5] F. Aligarh, A. Nugroho, B. S. Raharja, B. C. Pratama, and A. W. Wirayuda, "Do Individual Factors, Religiosity Factors, and Demographic Factors Predict Intention to Pay Zakat?," al-Uqud J. Islam. Econ., vol. 5, no. 1, pp. 151-165, 2020.

[6] R. Yusfiarto, A. Setiawan, and S. S. Nugraha, "Literacy and intention to pay zakat," Int. J. Zakat, vol. 5, no. 1, pp. 15-27, 2020.

[7] T. Mariyanti, P. Edastama, and M. H. M. Shafiai, "Factors Affecting Islamic Bank Customer Satisfaction," Aptisi Trans. Manag., vol. 5, no. 2, pp. 152-160, 2021.

[8] W. Setyowati and A. Sofingi, "Determinants of Employee Performance with Work Motivation as an Intervening Variable at the Semarang City Search and Rescue Office," APTISI Trans. Manag., vol. 6, no. 1, pp. 19-29, 2022.

[9] S. Purnama, C. S. Bangun, and S. A. Faaroek, "The Effect of Transaction Experience Using Digital Wallets on User Satisfaction in Millennial Generation," Aptisi Trans. Manag., vol. 5, no. 2, pp. 161-168, 2021.

[10] D. Mohammed, Q. Aini, D. Supriyanti, and M. Anggraeni, "Assimilate The Qur'an's View with Science and Technology Perspectives," Aptisi Trans. Technopreneursh., vol. 3, no. 1, pp. 42-47, 2021.

[11] J. Heikal, V. Rialialie, D. Rivelino, and I. A. Supriyono, "Hybrid Model Of Structural Equation Modeling Pls And Rfm (Recency, Frequency And Monetary) Model To Improve Bank Average Balance," Aptisi Trans. Technopreneursh., vol. 4, no. 1, pp. 1-8, 2022. 
[12] P. A. Sunarya, N. Lutfiani, N. P. L. Santoso, and R. A. Toyibah, "The Importance of Technology to the View of the Qur'an for Studying Natural Sciences," Aptisi Trans. Technopreneurship., vol. 3, no. 1, pp. 58-67, 2021.

[13] F. N. Syafira, R. T. Ratnasari, and S. Ismail, "The Effect Of Religiosity And Trust On Intention To Pay In Ziswaf Collection Through Digital Payments," JEBIS (Jurnal Ekon. dan Bisnis Islam., vol. 6 , no. 1, pp. 98-115, 2020.

[14] F. Azzahra and M. S. Abd Majid, "What Drives Muzakki to Pay Zakat at Baitul Mal?," Shirkah J. Econ. Bus., vol. 5, no. 1, pp. 27-52, 2020.

[15] M. Tho'in and A. Marimin, "Pengaruh Tingkat Pendapatan, Tingkat Pendidikan, dan Tingkat Religiusitas Terhadap Minat Muzakki Membayar Zakat," J. IIm. Ekon. Islam, vol. 5, no. 3, pp. 225-230, 2019.

[16] M. Tho'in and A. Marimin, "Faktor-Faktor Yang Mempengaruhi Minat Muzakki Dalam Membayar Zakat," in Prosiding Seminar Nasional \& Call for Paper STIE AAS, 2019, pp. 89-93.

[17] U. Rahardja, A. N. Hidayanto, N. Lutfiani, D. A. Febiani, and Q. Aini, "Immutability of Distributed Hash Model on Blockchain Node Storage," Sci. J. Informatics, vol. 8, no. 1, pp. 137-143, 2021.

[18] F. Setiawan, "Pengaruh religiusitas dan reputasi terhadap minat Muzakki dalam membayar Zakat profesi (Studi kasus di Kabupaten Ponorogo)," J. IImu Manaj., vol. 8, no. 1, pp. 1321, 2019.

[19] I. C. Utomo, S. Rokhmah, and I. Muslihah, "Web Based Distribution of Zakat, Infaq, and shodaqoh (Case Study Of Surakarta City Region)," Int. J. Comput. Inf. Syst., vol. 1, no. 1, pp. 16-21, 2020.

[20] N. M. Khalil, H. Amin, and N. S. Azman, "Compliance Intention to Pay Zakat on Salary," Int. J. Zakat, vol. 5, no. 2, pp. 37-50, 2020.

[21] E. Guustaaf, U. Rahardja, Q. Aini, H. W. Maharani, and N. A. Santoso, "Blockchain-based Education Project," Aptisi Trans. Manag., vol. 5, no. 1, pp. 46-61, 2021.

[22] F. N. Syafira, R. T. Ratnasari, and S. Ismail, "The Effect Of Religiosity And Trust On Intention To Pay In Ziswaf Collection Through Digital Payments," JEBIS (Jurnal Ekon. dan Bisnis Islam., vol. 6, no. 1, pp. 98-115, 2020.

[23] T. C. Husnadi, T. Marianti, and T. Ramadhan, "Determination of shareholders' welfare with financing quality as a moderating variable," APTISI Trans. Manag., vol. 6, no. 2, pp. 191208, 2022.

[24] A. K. Badri, J. Heikal, Y. A. Terah, and D. R. Nurjaman, "Decision-Making Techniques using LSTM on Antam Mining Shares before and during the COVID-19 Pandemic in Indonesia," APTISI Trans. Manag., vol. 6, no. 2, pp. 167-180, 2022.

[25] J. Artanti, P. M. Agustini, A. Saptono, G. K. Hanum, and D. O. Regina, "Analysis Of Virtual Product Marketing Strategies To Increase Customer Satisfaction (Case Study On Bukalapak Partners)," IAIC Trans. Sustain. Digit. Innov., vol. 3, no. 2, pp. 86-109, 2022.

[26] U. Rahardja, I. J. Dewanto, A. Djajadi, A. P. Candra, and M. Hardini, "Analysis of Covid 19 Data in Indonesia Using Supervised Emerging Patterns," APTISI Trans. Manag., vol. 6, no. 1, pp. 91-101, 2022. 
[27] N. Lutfiani, Q. Aini, U. Rahardja, L. Wijayanti, E. A. Nabila, and M. I. Ali, "Transformation of blockchain and opportunities for education 4.0," Int. J. Educ. Learn., vol. 3, no. 3, pp. 222231, 2021.

[28] S. Azizah and B. P. K. Bintoro, "Determining Factors of Continuance Intention to Use QR Code Mobile Payment on Urban Millennials in Indonesia Empirical Study on Mobile Payment Funds," ADI J. Recent Innov., vol. 3, no. 2, pp. 121-138, 2022.

[29] T. Ayuninggati, E. P. Harahap, D. Immaniar, and S. Amelia, "Peranan Tantangan Dakwah Pendidikan Agama Islam Dalam Media Komunikasi Era Globalisasi," Alph. J. Wawasan Agama Risal. Islam. Teknol. dan Sos., vol. 1, no. 1, pp. 85-95, 2021.

[30] A. Abror and A. Hudayati, "The effect of distributive justice on intention to pay zakat through zakat institutions using affective and cognitive trust as intervening variables," J. Ekon. dan Keuang. Islam, vol. 6, no. 1, pp. 24-33, 2020.

[31] A. C. Andam and A. Z. Osman, "Determinants of intention to give zakat on employment income: Experience from Marawi City, Philippines," J. Islam. Account. Bus. Res., 2019. 